\title{
The Family Satisfaction on Nursing Services at the Intensive Care Unit
}

Fitri Arofiati*, Puspa Apriliyanti

Department of Nursing, Universitas Muhammadiyah, Yogyakarta, Indonesia

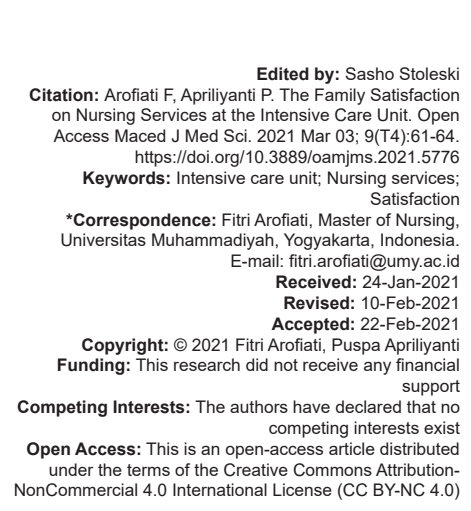

Introduction

Intensive care unit (ICU), according to the Decree of the Health Minister Number 1778/MENKES/ SK/XII/2010, is an independent part of the hospital with special staff and equipment intended for observation, treatment, and therapy of patients suffering from lifethreatening diseases and injuries with an uncertain prognosis. Based on the research conducted [1], it showed that there is a relationship between the quality of nursing services and patient family satisfaction in the ICU at Permata Medika Hospital Semarang. Satisfaction is an individual's feeling of pleasure when what is expected is in line with what is received. The good or poor quality of hospital services can be measured by the satisfaction of patients and families in receiving health services, especially nursing services. Nurses are a health profession that has an important role in providing health services. One of the services provided at the hospital is a nursing service which is the central point of other health services, carried out $24 \mathrm{~h}$ continuously. The essence of the concept of service quality is to show all forms of actualization of all service activities that satisfy those who receive services based on responsiveness, assurance, and tangibility. It can be perceived through people's empathy who provide services in accordance with their reliability in carrying out the service duties consequently to satisfy the patients [2]. Patient and family satisfaction is an important indicator to measure the quality of care in the ICU. The family dissatisfaction in the ICU is influenced by the attitudes and behavior of the staff including less communicative and informative nurses, the comfort of the waiting room, the ignorance and friendliness of the staff, and the easy access of information. Communication ranks highest in the perception of patient and family satisfaction in hospitals [3]. The aim of this study was to identify the level of family's satisfaction in nursing service at the ICU.

\section{Methods}

This research was non-experimental quantitative research using a descriptive research design with a cross-sectional approach. Descriptive research aims to explain a situation or important events in the present [4]. The population in this study was patients' families in the 
ICU PKU Muhammadiyah Hospital in Yogyakarta. The sampling technique used in this study was total sampling with 30 people. The inclusion criteria in this study were the family accompanying the patient for more than $24 \mathrm{~h}$, the patient's family who could read and write, and the patient's main family member or extended family. This research was conducted for 4 months, from February to June 2019. The variables in this study were a description of the level of family satisfaction in nursing services at the ICU. The instrument used in this study was a questionnaire rater to measure the level of family satisfaction. Data analysis using frequency distribution and displayed in table content.

\section{Results}

Based on Table 1, it can be perceived that the distribution of respondents based on age was mostly $41-56$ years old $(66.7 \%)$. Meanwhile, based on gender, the majority of respondents were female, with a total of 22 people $(73.3 \%)$. Based on the respondents' occupational data, most of the respondents were entrepreneurs with a total of 14 people $(46.7 \%)$, while the most recent educational background of the respondents was high school level with a total of 12 people (40.0\%).

Table 1: The distribution of the respondents' characteristic frequency $(n=30)$

\begin{tabular}{lll}
\hline Characteristic & $\mathrm{n}$ & $\%$ \\
\hline Age & & \\
$24-40$ & 10 & 33.3 \\
$41-56$ & 20 & 66.7 \\
Gender & & \\
$\quad$ Male & 8 & 26.7 \\
$\quad$ Female & 22 & 73.3 \\
Educational attainment & & \\
No educational background & 2 & 6.7 \\
Elementary school & 5 & 16.7 \\
Junior high school & 2 & 6.7 \\
Senior high school & 12 & 40.0 \\
Diploma & 2 & 6.7 \\
Bachelor & 7 & 23.3 \\
Occupation & & \\
Unemployed & 1 & 3.3 \\
Farmer & 1 & 3.3 \\
Civil servant & 5 & 16.7 \\
Entrepreneur & 14 & 46.7 \\
Housewife & 9 & 30.0 \\
Total & 30 & 100 \\
\hline
\end{tabular}

Based on Table 2, it can be perceived that the majority of respondents were satisfied with a total of 15 people $(50.0 \%)$, other $15(50.0 \%)$ respondents felt very satisfied, and none of the respondents felt dissatisfied or very dissatisfied with nursing services at the ICU PKU Muhammadiyah Hospital Yogyakarta.

Table 2: The frequency distribution of family's satisfaction level in nursing services at ICU PKU Muhammadiyah Hospital Yogyakarta

\begin{tabular}{lll}
\hline Level of satisfaction & $\mathrm{n}$ & $\%$ \\
\hline Very dissatisfied & 0 & 0 \\
Not satisfied & 0 & 0 \\
Satisfied & 15 & 50.0 \\
Very satisfied & 15 & 50.0 \\
Total & 30 & 100 \\
\hline ICU: Intensive care unit & &
\end{tabular}

Based on Table 3, it can be seen that the majority of respondents were satisfied with the nursing services at ICU PKU Muhammadiyah Hospital Yogyakarta, especially in the tangibility dimension with a total of 20 respondents $(66.3 \%)$, while the other 10 respondents $(33.7 \%)$ were very satisfied.

Table 3: The frequency distribution of family's satisfaction level in nursing services at ICU PKU Muhammadiyah Yogyakarta based on 5 dimensions

\begin{tabular}{lll}
\hline Satisfaction level & $\mathrm{n}$ & $\%$ \\
\hline Reliability & 18 & 60.0 \\
$\quad$ Satisfied & 12 & 40.0 \\
$\quad$ Very satisfied & & \\
Assurance & 18 & 60.0 \\
$\quad$ Satisfied & 12 & 40.0 \\
$\quad$ Very satisfied & & \\
Tangibility & 20 & 66.3 \\
$\quad$ Satisfied & 10 & 33.7 \\
$\quad$ Very satisfied & 12 & 40.0 \\
Empathy & 18 & 60.0 \\
$\quad$ Satisfied & & \\
$\quad$ Very satisfied & 17 & 56.7 \\
Responsiveness & 13 & 43.3 \\
$\quad$ Satisfied & 30 & 100 \\
$\quad$ Very satisfied & & \\
Total &
\end{tabular}

\section{Discussion}

\section{The description of a family's satisfaction in nursing services at ICU PKU Muhammadiyah Hospital Yogyakarta}

Satisfaction is a person's feeling of pleasure when what is expected is in line with what happens [2]. Based on the result of the research that has been conducted using the rater questionnaire, it is found that out of the 30 families of patients in ICU PKU Muhammadiyah Hospital Yogyakarta, most of them were satisfied with a total of 15 respondents $(50 \%)$, while other 15 respondents were very satisfied $(50 \%)$ with nursing services.

The high rate of family satisfaction is influenced by the service provided which is in line with the expectations of the patient's family based on 5 dimensions, such as reliability, assurance, tangibility, empathy, and responsiveness [5]. These results are also supported by a study showing that $26(65 \%)$ respondents were satisfied with the nursing services provided at the hospital. Satisfaction is a subjective feeling where everyone has different criteria according to their background. The higher the education of a person is, the more knowledge they will gain, and the more things they will demand [6].

\section{The description of the level of family satisfaction in nursing services based on the reliability dimension}

Reliability is an attitude that must be possessed by a nurse to provide fast, precise professional nursing services [7]. The result of the research conducted at ICU PKU Muhammadiyah Hospital Yogyakarta showed that based on the reliability dimension, most of the respondents were satisfied with a total of 18 people 
(60.0\%), while the other 15 respondents (40.0\%) felt very satisfied. The result is supported by the previous research stating that 99 respondents $(63 \%)$ were satisfied with the services provided by nurses at Bhayangkara Hospital III Kindergarten Manado. It indicates that nurses are able to provide services that are in line with the patients' family expectations precisely and accurately [8]

In the dimension of reliability, the most satisfying indicator is the nurses' ability which is the most dominant item with a total of 23 satisfied respondents (76.7\%). It is in line with the result of interviews showing that ICU PKU Muhammadiyah Hospital Yogyakarta always conducts nursing training. The more frequently a person attends the training, the more recent knowledge they will gain that enables them to improve their performance and morale [9]. Meanwhile, the highest rate for dissatisfaction feeling is communication about the availability of facilities, things that must be obeyed and prohibited in the ICU with a total of 2 respondents $(6.7 \%)$. In providing professional services, it is not only about nurses' skills and expertise but also about the nurse's communication skills. Based on interviews conducted with staff in the ICU, it revealed that nurses would tell about the things that were allowed and prohibited at the ICU the moment the patients enter the ICU room. In this case, there is a possibility that the patient's family, who was the respondent of the study, was not the family given the explanation when the patient entered the ICU.

\section{The description of the level of family satisfaction in nursing services based on the assurance dimension}

Assurance is the ability possessed by a nurse in providing services to patients and families and that patients and families feel confident about what nurses will and have done [10]. The result showed that 18 respondents $(60 \%)$ were satisfied with the assurance and $12(40 \%)$ respondents were satisfied with the empathy dimension of the nursing care at ICU PKU Muhammadiyah Hospital Yogyakarta. In ensuring the service quality, health workers must be professional, which can be seen through the capabilities in providing services, adequate knowledge, and the ability to convey information properly [11]. The indicator with the highest rate of satisfaction in the assurance dimension was the nurse's skill in handling nursing problems and that the majority of patients were satisfied with a total of 23 respondents $(76.7 \%)$. Nurses in ICU PKU Muhammadiyah Hospital Yogyakarta are those who have a long work period. The longer the work period of a nurse is the more experiences the nurse will gain and that their skills also increase [12].

\section{The description of the level of family satisfaction in nursing services based on tangibility dimensions}

Tangibility is the actual actualization of a service that can quickly be perceived and felt directly by the service user (patient and patient's family). Available facilities and infrastructure, service technology utilized, and a service provider performance are a form of physical evidence dimension [13]. Based on the research conducted, the result showed that 20 respondents (66.3\%) were satisfied, while the other 10 respondents (33.7\%) were very satisfied. Furthermore, the data revealed that more patients were satisfied. This study stated that physical evidence is a dimension that can be directly felt by customers (patients and patients' families) and has a strong relationship with a customer satisfaction rate. In this case, nurses can provide satisfactory services supported by facilities and infrastructure of the hospital so that the service can run optimally.

\section{The description of the level of family satisfaction in nursing services based on empathy dimension}

Empathy (empathy) is the ability possessed by nurses to understand the needs and give attention to consumers (patients and patients' families), communicate well, and foster good relationships [14]. Based on the research, the result showed that 12 respondents $(40 \%)$ were satisfied, while the other 18 respondents (60\%) felt very satisfied. A good understanding of consumer needs, a good communication, and friendly attitudes such as encouraging patients to recover, encouraging families to always accompany the patients, and praying for patients to recover quickly are part of the nurse's empathy behavior [15]. The indicator with the highest rate of satisfaction was that the nurses do not discriminate the patients in terms of treatment, with a total of 22 respondents (73.3\%). In this case, the health workers tend to provide explanations that are easy to understand, provide services based on the needs of consumers (patients and families), always ask permission from the family before taking a nursing action, and do not discriminate between general patients and patients using health insurance (BPJS).

Meanwhile, the indicator with the highest rate of dissatisfaction was the nurse's lack of concern about the patients' condition, with a total of 10 respondents $(33.3 \%)$. The nurse's time constraint and the nurse's heavy responsibility in maintaining patient homeostatic conditions cause the nurse's lack of interaction with the patient's family [16].

\section{The description of the level of family satisfaction in nursing services based on the responsiveness dimension}

Responsiveness is the willingness or availability of nurses to provide immediate services and listen to the customers' complaints [12]. Based on the result of the study, it was found that 17 respondents (56.7\%) were satisfied, while the other 13 respondents (43.3\%) were very satisfied. In an ICU hospital, patients' emergency conditions can occur at any time and that health workers, especially nurses, have to make an optimal 
effort to resolve the problem quickly and accurately. As the problem can be well handled, consumers will be satisfied with the service since the responsiveness has a positive relationship with customer satisfaction [17].

The indicator with the highest level of satisfaction is that the nurse is able to well provide medical drugs with a total of 23 respondents $(76.7 \%)$. In the drug administration, there are five stages, such as administrating, prescribing, documenting, dispensing, and monitoring. All of the stages are carried out by health workers in which nurses are committed to carrying out three stages, such as administrating, documenting, and monitoring. In this case, the health workers have to commit their duty properly and that consumers (family of patients) feel satisfied with the service [18].

\section{Conclusion}

All respondents were satisfied with the nursing services at ICU PKU Muhammadiyah Hospital Yogyakarta with the dimension of reliability, assurance, physical evidence of the nursing services (tangibility), empathy, and responsiveness.

Nurses should pay attention and maintain good service. The hospital should conduct a periodic survey to review the patient and family satisfaction to evaluate the performance of the nurses. The patient's family should provide honest answers in the periodic survey. Therefore, inadequate services can be improved immediately and the family of the patient can benefit it.

\section{Acknowledgments}

Researchers would like to thanks to Universitas Muhammadiyah Yogyakarta for all of support during the process of the research and all of participants from the ICU PKU Muhammadiyah Hospital.

\section{References}

1. Retnaningsing $D$, Aini DN, Yulianti I. Satisfaction of the patient's Family in the ICU of Permata Medika Hospital, Semarang. J Kesehatan Kusuma Husada. 2017;8(1):1-10.

2. Nursalam N. Nursing Management: Application in Professional Nursing Practice. 3rd ed. Jkt Salemba Med. 2007; 42-57.

3. DeSanto-Madeya S, Safizadeh P. Family satisfaction with endof-life care in the intensive care unit: A systematic review of the literature. Dimens Crit Care Nurs. 2017;36(5):278-83. https:// doi.org/10.1097/dcc. 0000000000000262

PMid:28777113
4. Nursalam M. Nursing Science Research Methodology. 4th ed. Jkt Salemba Med. 2015; 49-54.

5. Bayatmanesh H, Tafreshi MZ, Mnoochehri H, Baghban AA. Evaluation of patient-related nursing care with standards in intensive care unit (ICU). Armaghane Danesh. 2017;22(3):375-89.

6. Heyland DK, Rocker GM, Dodek PM, Kutsogiannis DJ Konopad E, Cook DJ, et al. Family satisfaction with care in the intensive care unit: Results of a multiple center study. Crit Care Med. 2002;30(7):1413-8. https://doi. org/10.1097/00003246-200207000-00002

PMid: 12130954

7. Clark K, Milner KA, Beck M, Mason V. Measuring family satisfaction with care delivered in the intensive care unit. Crit Care Nurse. 2016;36(6):e8-14. https://doi.org/10.4037/ ccn2016276

PMid:27908955

8. China P. Rumayar AA, Engkeng S. Relationship Between Patient's Satisfaction Towards Quality of Nurse Services at Bhayangkara Hospital, Level III Manado. J Med Kesehatan. 2017;9(3):31-40

9. Brack S, Sandford M. Partnerships in intensive care unit (ICU): A new model of nursing care delivery. Aust Crit Care. 2011;24(2):101-9. https://doi.org/10.1016/j.aucc.2010.12.001 PMid:21273091

10. Goh ML, Ang EN, Chan YH, He HG, Vehviläinen-Julkunen K. A descriptive quantitative study on multi-ethnic patient satisfaction with nursing care measured by the revised humane caring scale. Appl Nurs Res. 2016;31:126-31. https://doi.org/10.1016/j. apnr.2016.02.002 PMid:27397830

11. Kol E, Arıkan F, İlaslan E, Akıncı MA, Koçak MC. A quality indicator for the evaluation of nursing care: Determination of patient satisfaction and related factors at a university hospital in the Mediterranean region in Turkey. Collegian. 2018;25(1):51-6. https://doi.org/10.1016/j.colegn.2017.03.006

12. Jung SM, Yoon SH. Comparative analysis research of inpatient satisfaction with nursing on comprehensive nursing service units and general units and nurses' work stress. J Korean Acad Nurs Adm. 2017;23(3):229-38. https://doi.org/10.11111/ jkana.2017.23.3.229

13. Mulugeta $H$, Wagnew F, Dessie G, Biresaw H, Habtewold TD. Patient satisfaction with nursing care in Ethiopia: A systematic review and meta-analysis. BMC Nurs. 2019;18(1):27. https:// doi.org/10.1186/s12912-019-0348-9

14. Rajabpour S, Rayyani M. The relationship between Iranian patients' perception of holistic care and satisfaction with nursing care. BMC Nurs. 2019;18(1):1-7. https://doi.org/10.1186/ s12912-019-0374-7

15. Jensen HI, Gerritsen RT, Koopmans M, Downey L, Engelberg RA, Curtis JR, et al. Satisfaction with quality of ICU care for patients and families: The euroQ2 project. Crit Care. 2017;21(1):239. https://doi.org/10.1186/s13054-017-1826-7 PMid:28882192

16. Camelo SH. Professional competences of nurse to work in intensive care units: An integrative review. Rev Lat Am Enfermagem. 2012;20(1):192-200. https://doi.org/10.1590/ s0104-11692012000100025

17. Urden LD, Stacy KM, Lough ME. Critical Care Nursing-E-Book: Diagnosis and Management. Netherlands: Elsevier Health Sciences; 2017. p. 1109.

18. van den Broek JM, Brunsveld-Reinders $A H$, Zedlitz AM, Girbes ARJ, de Jonge $E$, et al. Questionnaires on family satisfaction in the adult ICU: A systematic review including psychometric properties. Crit Care Med. 2015;43(8):1731-44. https://doi.org/10.1097/ccm.0000000000000980

PMid:25821917 